\title{
INTRAOPERATIVE HYPOXEMIA DURING ONE-LUNG VENTILATION: IS IT STILL AN ANESTHESIOLOGISTS’ NIGHTMARE? (HYPOXEMIA DURING ONE-LUNG VENTILATION)
}

\author{
Radmilo J Janković ${ }^{1,2}$, Milena Stojanović ${ }^{1}$, Anita Vuković ${ }^{1}$, Vesna Dinić ${ }^{1}$, Vladan Cvetanović ${ }^{1}$, Danica Marković ${ }^{1}$ \\ ${ }^{1}$ Clinic for Anesthesia and Intensive Therapy, Clinical Center Niš \\ ${ }^{2}$ School of Medicine, University of Niš, Serbia
}

\begin{abstract}
Sažetak
Ventilacija jednog plućnog krila se koristi iz različitih hirurških i ne-hirurških razloga. Ovaj tip ventilacije nosi sa sobom određene rizike za razvoj ventilaciono/perfuzionih poremećaja različitog stepena povezanim sa lateralnim dekubitalnim položajem, jednostranom plućnom ventilacijom i otvaranjem grudnog koša. Kako je hipoksemija jedna od posledica jednostrane plućne ventilacije, različite strategije ventilacije se preporučuju u cilju njene prevencije i lečenja. Strategija uključuje odredene manevre na ventilišućem i ne-ventilišućem plućnom krilu kao $i$ upotrebu odredenih lekova koji mogu modulirati i intenzivirati fenomen jedinstven za plućnu cirkulaciju- hipoksičnu plućnu vazokontrikciju (HPV).
\end{abstract}

Ključne reči: hipoksemija, jednostrana ventilacija pluća, hipoksična plućna vazokonstrikcija

\section{Pathophysiological mechanism of hypoxemia during one-lung ventilation}

$\mathrm{O}$ ne of the most challenging procedures for anesthesiologist is technique that includes isolation of one lung from ventilation (One Lung Ventilation - OLV). It is not easy to maintain adequate gas exchange during OLV and provide an optimal surgical field, so hypoxemia is an adverse but common consequence of OLV. Hypoxemia during one-lung ventilation (OLV) can be defined as an arterial hemoglobin oxygen saturation of less than $90 \%$, which occurs in $5-10 \%$ of patients (that undergo this procedure). ${ }^{1}$ The underlying patophysiological cause of hypoxemia is attributed to intrapulmonary shunt. ${ }^{2}$

\section{Sumarry}

Lung isolation is used for various surgical and non-surgical reasons. This type of ventilation carries the risk for various degrees of ventilation/perfusion mismatch associated with lateral decubitus position, one-lung ventilation $(O L V)$ and opened chest. According to this, hypoxemia is common consequence of OLV. Among various recommended ventilation strategies in order to prevent hypoxemia, protective ventilation with lower tidal volumes and applied positive end-expiratory (PEEP) pressure give some promising results. Adequate treatment and possibility to predict hypoxemia during OLV is very important for reducing morbidity and mortality. Treatment includes ventilator strategies on both, ventilated and non-ventilated lung and applied therapy, which can influence and modulate the magnitude of phenomenon unique for lung circulation - hypoxic pulmonary vasoconstriction (HPV).

Key words: hypoxemia, one lung ventilation, hypoxic pulmonary vasoconstriction

Basic characteristics during anesthesia with OLV are lateral decubitus position, lung isolation and open chest. Using the double - lumen bronchial tube or bronchial blocker, the lower (dependent) lung is ventilated, whereas the upper (non-dependent) lung is allowed to collapse when opening the chest. Development of hypoxemia (i.e. arterial oxygenation $<90 \%$, or $\mathrm{PaO}_{2}<60 \mathrm{mmHg}$ with $\mathrm{FiO} 2=1.0$ ) caused by OLV may be explained by taking into consideration: oxygen storage, dissociation of oxygen from hemoglobin, the relationship between ventilation and perfusion and factors that reduce the effect of hypoxic pulmonary vasoconstriction (HPV). ${ }^{3}$

Factors that potentially increase the risk of hypoxemia during OLV are: right-sided thoracic 
surgery and left side ventilation, high percentage of ventilation or perfusion to the operative lung on preoperative $\mathrm{V} / \mathrm{Q}$ scan, normal preoperative spirometry, low $\mathrm{PaO}_{2}$ during two lung ventilation (TLV) in lateral position, $\mathrm{BMI}>30 \mathrm{~kg} / \mathrm{m}^{2}$, previous lobectomy and contralateral lung collapse surgery. ${ }^{4}$

\section{Ventilation-perfusion mismatching}

The lateral position may significantly alter the normal pulmonary ventilation/perfusion ratio. This position in spontaneously breathing patient does not alter the ventilation-perfusion ratio, since the dependent lung receives more perfusion and more ventilation (contraction of the dependent parts of hemidiaphragm is more efficient) than the non-dependent lung. The relationship of ventilation and perfusion changes after induction of anesthesia. During controlled positive-pressure ventilation, in terms of ventilation the upper lung is in more favorable position because its higher compliance, whereas perfusion remains greater in the lower (dependent) lung. Use of neuromuscular blocking agents and opening the chest enhance this effect. Perfusion of the non-dependent lung without ventilation leads to development a large rightto-left intrapulmonary shunt and consequently to hypoxemia and hypercapnia. ${ }^{5}$ Due to HPV clinically observed shunt fraction is lower than roughly half of the cardiac output (CO) that normally flows through each lung. ${ }^{6}$ It is generally assumed that due to gravity $60 \%$ of blood will flow through the dependent lung, with the remaining $40 \%$ perfusing through the non-dependent lung. Because total shunt ( $10 \%$ of cardiac output) is roughly equally divided, $55 \%$ and $35 \%$ of CO participate in gas exchange, respectively. Ventilating the dependent lung only will result in loss of $35 \%$ of CO that participates in gas exchange (non-dependent lung). Hypoxic pulmonary vasoconstriction can decrease non-dependent blood flow by $50 \%$ (or $17.5 \%$ globally), thus the amount of CO available for gas exchange should only fall from $90 \%$ to $72.5 \%$. That said, because of abdominal content, paralysis, anesthesia and the weight of mediastinal structures, the dependent lung has reduced FRC and is relatively non-compliant. ${ }^{7}$

\section{The impact of ventilation strategy and pa- tient positioning on intraoperative hypox- emia during one-lung ventilation}

In order to prevent acute lung injury (ALI) in thoracic anesthesia procedures, the concept of protective OLV has been widely adopted in the past few years. ${ }^{8}$ This ventilation strategy includes the use of lower tidal volumes $(5-6 \mathrm{ml} / \mathrm{kg})$, positive end-expiratory pressure-PEEP $\left(5-10 \mathrm{~cm} \mathrm{H}_{2} \mathrm{O}\right)$, lower $\mathrm{FiO}_{2}$ (50-80\%) and permissive hypercapnia, The effects of this ventilation strategy on intraoperative hypoxemia still remains controversial ${ }^{9,10}$ but it looks like hypercapnia, as part of a protective ventilation, is felt to improve HPV and therefore aid oxygenation. ${ }^{11}$ Gao et al. showed in their study that therapeutic hypercapnia improves respiratory function, and mitigate OLV-related lung and systemic inflammation. ${ }^{12}$ Using lower tidal volumes may be associated with derecruitment, worsening intraoperative atelectasis and intrapulmonary shunt, thus contributing to hypoxemia and hipercapnia. ${ }^{13}$ This can be prevented by addition of PEEP which can reduce the incidence of atelectasis by preventing lung collapse. Also, prolonging the inspiratory time and adjusting the I:E ratio can be effective in improving oxygenation and reducing shunt fraction about one hour after starting the OLV. ${ }^{14}$

Although for now, there is not enough evidence about which ventilation mode is preferable, pressure-control ventilation (PCV) is thought to provide more uniform lung aeration and recruitment as well as lower risk of barotrauma by limiting the peak $\left(<35 \mathrm{~cm} \mathrm{H}_{2} \mathrm{O}\right)$ and plateau airway pressure $\left(<25 \mathrm{~cm} \mathrm{H}_{2} \mathrm{O}\right)$. Indeed, initial studies comparing PCV and volume-control ventilation (VCV) during OLV found improved oxygenation and shunt fraction with $\mathrm{PCV}^{15}$, as well as the risk reduction for post-thoracotomy acute lung injury, but subsequent investigations failed to highlight benefit of PCV during OLV. ${ }^{8,}$ 16-18

Traditionally, the lateral decubitus position has been found to improve oxygenation during OLV due to gravity redistribution of pulmonary blood flow with diverting roughly $10 \%$ of CO to the dependent lung. ${ }^{19}$ On the other hand, Yatabe et al. found better $\mathrm{PaO}_{2} / \mathrm{FiO}_{2}$ ratios in patients undergoing oesophagectomy in prone position. ${ }^{20}$ This finding may be explained by the superior V/Q 
matching in the prone position ${ }^{21}$ and the lack of compression of the ventilated lung by mediastinal structures. ${ }^{22}$ Additionally, supine positioning during some thoracoscopic procedures also tends to increase the risk of hypoxemia during OLV. ${ }^{23}$ However, recent animal experiments appear to suggest that anatomic pulmonary vascular factors are more important than gravity per se in terms of pulmonary blood flow distribution (it depends on lung volume, body position and PEEP). In the opposite of expectations, the blood flow through the dependent lung can be reduced. One of possible explanation is that the pressure of mediastinal structures could reduces ventilation of the dependent lug. This consequently provokes hypoxic pulmonary vasoconstriction and decreases blood flow. ${ }^{24}$

\section{Treatment of hypoxemia}

\section{Interventions directed to depended lung}

One of the most efficient ways to treat hypoxemia during OLV is alveolar recruitment maneuver of the dependent lung. ${ }^{25}$ It can be applied before starting OLV with 10 breaths limited with plateau pressure of $40 \mathrm{~cm} \mathrm{H} \mathrm{H}_{2} \mathrm{O}$ and PEEP in incremental levels of $5-10 \mathrm{cmH}_{2} \mathrm{O}$ with maximum PEEP of $20 \mathrm{~cm} \mathrm{H}_{2} \mathrm{O}^{26}$ This maneuver can be continued on the dependent lung during OLV in a duration of 1 minute and application of $5 \mathrm{~cm} \mathrm{H}_{2} \mathrm{O}$ PEEP. $^{27,28}$ By increasing the area of ventilated lung parenchyma, this maneuver improves gas exchange and arterial oxygenation. Furthermore, in major pulmonary resection, the alveolar recruitment maneuver has improved arterial oxygenation by reducing intrapulmonary shunt and dead space during OLV. ${ }^{15,29}$ On the other hand, this strategy may lead to hemodynamic instability by decreasing the left ventricular preload, $\mathrm{CO}$ and arterial blood pressure ${ }^{30,31}$, and may also cause barotrau$\mathrm{ma}^{32}$ and translocation of pro-inflammatory cytokines from the alveolar space into the systemic circulation. ${ }^{33}$ We can conclude that dependent lung recruitment might be effective for arterial oxygenation improvement during OLV, however, its final effect can be transient. ${ }^{34}$

\section{Interventions directed to non-depended lung}

When severe hypoxemia occurs, intermittent two-lung ventilation and application of continuous positive airway pressure (CPAP) to the non-dependent lung may be effective. Another advantage of using CPAP is that this maneuver reduces local immune response after OLV, as shown by Verhage et al. during thoracoscopic oesophagectomy. ${ }^{35}$ However, this technique can interfere with surgical procedure, especially with video-assisted thoracoscopic surgery (VATS) since it impairs the view of the surgical field. This limits the use of CPAP of the non-dependent lung in clinical practice. In order to overcome this limit, modifications of the standard CPAP technique are proposed. These new techniques include a novel method of fibreoptic bronchoscopic selective oxygen insufflation into a bronchopulmonary segment in order to clear the surgical site ${ }^{36}$ and intermittent small-volume oxygen insufflations. ${ }^{37}$ In cases of disastrous desaturation, clamping the pulmonary artery may improve oxygenation. 38,39

Making a compression on the nondependent lung by surgeons is one of the additional maneuver for improving oxygenation during OLV. This controversial strategy also decreases CO and systemic oxygen delivery, but Ishikawa et al. found that administration of an inotropic agent concomitant with lung compression mitigates the decreases in $\mathrm{CO}$ and systemic oxygen delivery, while maintaining the beneficial effect of lung compression on arterial oxygen saturation. ${ }^{40}$ High-frequency jet ventilation and high-frequency percussive ventilation also appear successful in treating hypoxemia during OLV without impeding surgical exposure. ${ }^{41,42}$

\section{Medications}

Shunt fraction is the (most important) determinant of oxygenation during OLV and therefore agents which increase the pulmonary blood flow in the ventilated lung may significantly improve oxygenation. Selective vasodilatation of the pulmonary vascular bed may be achieved with inhalational agents. Inhaled nitric oxide (NO) has pulmonary vasodilating, bronchodilating and anti-inflammatory effects. Prostacycline and Alprostadil reduce pulmonary vascular resistance and improve oxygenation, however, all of these agents are expensive and can not be considered a readily available treatment. ${ }^{43,44,45}$

Almitrinine acts as a selective pulmonary vasoconstrictor which increases HPV and decreases 
the shunt fraction. Intravenous infusion of $8 \mu \mathrm{g} /$ $\mathrm{kg} / \mathrm{min}$ of this agent significantly improves oxygenation. Some authors suggest the combination of almitrinine and NO, however, almitrinine is not yet commercially available in some parts of the world. ${ }^{46,47}$

Epidural dexmedetomidine has been shown to limit the decrease in $\mathrm{PaO}_{2}$ during OLV without affecting systemic or pulmonary hemodynamic parameters. ${ }^{48}$ This action of dexmedetomidine may be explained by nitric oxide dependent vasodilatation mediated by endothelial a 2-adrenoceptor activation. ${ }^{49}$ Also, aerosolized epoprostenol has been shown to improve arterial oxygenation and decrease mean pulmonary artery pressure in patients with acute respiratory distress syndrome, presumably through dilation of the pulmonary vascular bed in ventilated regions and flow redistribution from shunt areas. ${ }^{50}$ Despite limited reports, it seems that epoprostenol may improve critical desaturation during $\mathrm{OLV}^{51}$ but larger clinical trials are required to establish its safety and efficacy profile during OLV.

\section{The influence of anesthetic technique on HPV}

As previously stated, HPV is the most important intraoperative phenomenon in reducing shunt during OLV. This protective physiological reflex occurs with the aim to divert blood flow from hypoxic areas to the regions of better oxygenation and ventilation, and it can decrease the blood flow in non-ventilated lung for about 50\%..(7) The stimuli for HPV are the alveolar oxygen tension and the partial pressure of oxygen in mixed venous blood, but it seems that the first one is more important. The threshold for HPV is alveolar oxygen tension of about $80 \mathrm{mmHg}$, and maximum response is with $\mathrm{PaO}_{2}$ of $25 \mathrm{mmHg}{ }^{52}$ Various factors (anesthetic agent, $\mathrm{CO}$, acid/base imbalance, lung manipulation, vasodilatators) can modulate the magnitude of HPV in the non-ventilated lung. Also, a series of physiological factors can influence the HPV mechanism, like: extracellular $\mathrm{pH}$ and $\mathrm{PCO}_{2}$, temperature, age and iron status. Pulmonary arterial pressure is increased by hypercapnia, acidaemia, hyperthermia, lower age, iron deficiency. ${ }^{53}$ Also, surgical trauma may lead to release of vasoactive metabolites and oppose HPV. ${ }^{54}$ In animal studies, volatile anesthetics have been shown to im- pair HPV and to increase intrapulmonary shunt fraction or reduce arterial oxygen tension in a dose-dependent manner ${ }^{55,56}$, while propofol does not seem to affect HPV. However, clinical investigations are contradictory regarding the effect of a given anesthetic agent on oxygenation. ${ }^{57-61}$

A combination of almitrin, which reinforces HPV in non-dependent lung areas and nitrous oxide in dependent lung, which reduces pulmonary vasoconstriction, may be useful during hypoxia and OLV. Use of almitirine as a selective lung vasoconstrictor is recommended when other strategies fail to improve hypoxemia. ${ }^{62}$

One of additional saving maneuvers that can be used for improving oxygenation during OLV is extracorporeal membrane oxygenation (ECMO). The major indications are: severe airway obstruction, emergence loss of airway, extended carinal pneumonectomy, severe emphysema undergoing lung volume reduction, acute respiratory distress syndrome undergoing thoracotomy and decortications, tracheoesophageal fistula repair after previous pneumonectomy, oesophagectomy after previous pneumonectomy, segmentectomy after previous contralateral pneumonectomy, thoracotomy after previous single-lung transplantation, thoracotomy with existing contralateral bronchopleural fistula and salvage therapy for severe chest trauma. ${ }^{4}$

\section{Prediction of hypoxemia}

\section{Capnometry}

The ability to predict which patients are most likely to have impaired arterial oxygenation would allow anesthesiologists to consider applying continuous positive airway pressure (CPAP) to the nondependent lung and positive end-expiratory pressure (PEEP) to the dependent lung at a very early stage in OLV. The percentage of non-dependent lung perfusion, is an important predictor of arterial oxygenation during OLV. ${ }^{63}$ On the other hand, capnometry might be used to estimate the balance of blood flow to both lungs and to predict the occurrence of hypoxemia during OLV. ${ }^{64,65}$ Two recent studies presented by Fukuoka et al. and Yamamoto et al. found a significant linear relationship between $\mathrm{ETCO}_{2}$ and the $\mathrm{PaO}_{2} / \mathrm{FiO}_{2}$ ratio af- 
ter starting OLV, as $\mathrm{ETO}_{2}$ depends on perfusion, it can be predictable parameter OLV hypoxemia occurance. ${ }^{61,66}$

\section{Tissue oxygenation}

At present, cerebral oximetry is the only noninvasive monitor available to determine tissue oxygenation during OLV. Decreased levels of cerebral tissue oxygen saturation obtained by noninvasive cerebral oxygen monitoring were found in the majority of patients during OLV. ${ }^{67}$ Further research which would determine the final end-organ effects of OLV on other organ systems are necessary and further technical development of noninvasive organ monitors is needed.

\section{Conclusion}

Besides carrying the risk of developing barotrauma, one lung ventilation (OLV) carries the risk of developing hypoxemia and hypercapnia due to intrapulmonary shunting and dead space ventilation. Both of these can have a significant effect on perioperative anesthesia management and postoperative complications. Today's techniques and medications can mitigate these consequences of OLV, but the problem that still remains is the lack of equipment in some medical centers and the fact that some medications are not available in all countries.

The key point in preventing postoperative complications in thoracic surgery is applying the right ventilatory strategy. There are no published guidelines, however, it seems reasonable to use protective ventilation mode to minimize the risk of lung trauma and acute lung injury (ALI). Despite the growing awareness of the importance of protective ventilation, many clinicians still use tidal volume and PEEP outside the recommended levels in everyday practice.

\section{References:}

1. Hadrien Roze, Mathieu Lafargue, Alexandre Ouattara. Case scenario: Management of intraoperative hypoxemia during one-lung ventilation. Anesthesiology 2011;114:167-174.

2. Malay Sarkar, N Niranjan, PK Banyal.Mechanisms of hypoxemia.Lung India. 2017; 34(1): 47-60.

3. Atul Purohit, Suresh Bhargava, Vandana Mangal, Vinod Kumar Parashar. Lung isolation, one-lung ventilation. Hypoxaemia during lung isolation. Indian J Anaesth. 2015;59(9):606-617.
4. Campos JH, Feider A. Hypoxia During One-Lung Ventilation-A Review and Update. Journal of Cardiothoracic and Vascular Anesthesia. In press http://dx.doi.org/10.1053/j.jvca.2017.12.026

5. Brassard CL, Lohser J, Donati F, Bussie 'res JS. Step-by-step clinical management of one lung ventilation: Continuing Professional Development. Can J Anesth 2014; 61: 1103-1121.

6. Walsh MA, Lohser J. Arterial oxygenation and Management of Hypoxia During VATS. Curr Anesthesiol Rep 2014; 4: 170-176

7. Positioning in Thoracic Surgery. https: // www. openanesthesia. org/ positioning_in_thoracic_surgery

8. Licker M, Diaper J, Villiger Y, et al. Impact of intraoperative lung-protective interventions in patients undergoing lung cancer surgery. Crit Care 2009; 13: R41.

9. Lohser J. Evidence-based management of one-lung ventilation. Anesthesiol Clin 2008; 26: 241- 72.

10. Theroux MC, Fisher AO, Horner LM, et al. Protective ventilation to reduce inflammatory injury from one lung ventilation in a piglet model. Pediatr Anaesth 2010; 20: 356-64.

11. Balanos GM, Talbot NP, Dorrington KL, Robbins PA. Human pulmonary vascular response to $4 \mathrm{~h}$ of hypercapnia and hypocapnia measured using Doppler echocardiography. J Appl Physiol 2003; 94: 1543-51.

12. Gao W, Liu D, Li D, Cui G. Effect of Therapeutic Hypercapnia on Inflammatory Responses to One-lung Ventilation in Lobectomy Patients. Anesthesiology 2015; 122: 1235-1252.

13. Yang M, Ahn HJ, Kim K, Kim JA, Yi CA, Kim MJ, et al. Does a protective ventilation strategy reduce the risk of pulmonary complications after lung cancer surgery? A randomized con-trolled trial. Chest. 2011; 139: 530-7.

14. Lee SM, Kim WH, Ahn HJ, Kim JA, Yan MK, Lee CH, Lee H, Kim YR, Choi6 YW. The effects of prolonged inspiratory time during one-lung ventilation: a randomised controlled trial. Anesthesia 2013; 68: 908-816.

15. Tugrul M, Camci H, Karadeniz M, et al. Comparison of volume controlled with pressure controlled ventilation during one-lung anaesthesia. Br J Anaesth 1997; 79: 306-10.

16. Unzueta MC, Casas JI, Moral MV. Pressure-controlled versus volume-controlledventilation during one-lung ventilation for thoracic surgery. Anesth Analg 2007; 104: 1029-33.

17. Pardos PC, Garutti I, Pineiro P, et al. Effects of ventilatory mode during one lung ventilation on intraoperative and postoperative arterial oxygenation in thoracic surgery. J Cardiothorac Vasc Anesth 2009; 23: 770-4.

18. Choi YS, Shim JK, Na S, et al. Pressure- controlled versus volume- controlled ventilation during one-lung ventilation in the prone position for robot-assisted esophagectomy. Surg Endosc 2009; 23: 2286-91.

19. Neustein SM, Eisenkraft JB, Cohen E. Chapter 40 Anesthesia for thoracic surgery. In Barash PG, Cullen BF, Stoelting RK, et al., editors. Clinical anesthesia. 6th ed. Lippincott Williams \& Wilkins: Philadelphia; 2009. pp. 1032-72.

20. Yatabe T, Kitagawa H, Yamashita K, et al. Better postoperative oxygenation in thoracoscopic esophagectomy in prone positioning. J Anesth 2010; 24: 803-6.

21. Nyren S, Radell P, Lindahl SG, et al. Lung ventilation and perfusion in prone and supine postures with reference to 
anesthetized and mechanically ventilated healthy volunteers. Anesthesiology 2010; 112: 682-7.

22. Pelosi P, Croci M, Calappi E, et al. The prone positioning during general anesthesia minimally affects respiratory mechanics while improving functional residual capacity and increasing oxygen tension. Anesth Analg 1995; 80: 955-60.

23. Darlong LM. Video-assisted thoracic surgery for superior posterior mediastinal neurogenic tumour in the spine position. J Minim Access Surg 2009; 5: 49-51.

24. Chang H, Lai-Fook SJ, Domino KB, et al. Spatial distribution of ventilation and perfusion in anesthetized dogs in the lateral postures. J Appl Physiol 2002; 92: 745-2.

25. Tusman G, Bo“hm SH, Sipmann FS, Maisch S. Lung recruitment improves the efficiency of ventilation and gas exchange during one-lung ventilation anesthesia. Anesth Analg 2004; 98: 1604-09.

26. Richard JC, Maggiore SM, Jonson B, Mancebo J, Lemaire F, Brochard L. Influence of tidal volume on alveolar recruitment: Respective ole of PEEP and a recruitment maneuver. Am J Respir Crit Care Med 2001;163(7):1609-13.

27. Unzueta C, Tusman G, Suarez-Sipmann, et al. Alveolar recruitment improves ventilation during thoracic surgery: A randomized controlled trial. Br J Anaesth 2012; 108: 517-24.

28. Cinnella G, Grasso S, Natale C, et al. Physiological effects of a lung recruiting strategy applied during one-lung ventilation. Acta Anaesthesiol Scand 2008; 52: 766-75.

29. Tusman G, Bohm SH, Melkun F, et al. Alveolar recruitment strategy increases arterial oxygenation during one-lung ventilation. Ann Thorac Surg 2002; 73: 1204-09.

30. Syring RS, Otto CM, Spivack RE, et al. Maintenance of end-expiratory recruitment with increased respiratory rate after saline-lavage lung injury. J Appl Physiol 2007; 102: 331-9.

31. Garutti I, Martinez G, Cruz P, et al. The impact of lung recruitment on hemodynamics during one-lung ventilation. J Cardiothorac Vasc Anesth 2009; 23: 506-8.

32. Meade MO, Cook DJ, Griffith LE, et al. A study of the physiologic responses to a lung recruitment maneuver in acute lung injury and acute respiratory distress syndrome. Respir Care 2008; 53: 1441-9.

33. Halbertsma FJ, Vaneker M, Pickkers P, et al. A single recruitment maneuver in ventilated critically ill children can translocate pulmonary cytokines into the circulation. J Crit Care 2010; 25: 10-15.

34. Lumb AB, Greenhill SJ, Simpson MP, Stewart J. Lung recruitment and positive airway pressure before extubation does not improve oxygenation in the postanaesthesia care unit: a randomized clinical trial. Br J Anaesth 2010; 104: 643-7.

35. Verhage RJ, Boone J, Rijkers GT, Cromheecke GJ, Kroese AC, Weijs TJ, Borel Rinkes IH, van Hillegersberg R. Reduced local immune response with continuous positive airway pressure during one-lung ventilation for oesophagectomy. Br J Anaesth._2014; 112(5): 920-8.

36. Ku CM, Slinger P, Waddell TK. A novel method of treating hypoxemia during one-lung ventilation for thoracoscopic surgery. J Cardiothorac Vasc Anesth 2009; 23: 850-2.

37. Russell WJ. Intermittent positive airway pressure to manage hypoxia during one-lung anaesthesia. Anaesth Intensive Care 2009; 37:432-4.
38. Trytko RL. Preventing hypoxemia during pulmonary sleeve resections. Anesth Analg 2006;103:497.

39. Kamiyoshihara M, Nagashima T, Ibe T, Takeyoshi I. A tip for controlling the main pulmonary artery during video-assisted thoracic major pulmonary resection: the outside-field vascular clamping technique. Interact Cardiovasc Thorac Surg. 2010;11(5):693-5.)

40. Ishikawa S, Shirasawa M, Fujisawa M, et al. Compressing the nondependent lung during one-lung ventilation improves arterial oxygenation, but impairs systemic oxygen delivery by decreasing cardiac output. J Anesth 2010; 24: 17-23.

41. Ender J, Brodowsky M, Falk V, et al. High-frequency jet ventilation as an alternative method compared to conventional one-lung ventilation using double-lumen tubes: a study of 40 patients undergoing minimally invasive coronary artery bypass graft surgery. J Cardiothorac Vasc Anesth 2010; 24: 602-7.

42. Lucangelo U, Antonaglia V, Zin WA, et al. High-frequency percussive ventilation improves perioperatively clinical evolution in pulmonary resection. Crit Care Med 2009; 37:1663-9.

43. Walsh AM, Lohser J. Arterial oxygenation and management of hypoxemia during VATS. Current Anesthesiology Reports 2014; 4(2): 170-6.

44. Rich GF, Lowson SM, Johns RA, Daugherty MO, Uncles DR. Inhaled nitric oxide selectively decreases pulmonary vascular resistance without impairing oxygenation during one-lung ventilation in patients undergoing cardiac surgery. Anesthesiology. 1994;80(1):57-62. Walsh AM, Lohser J. Arterial oxygenation and management of hypoxemia during VATS. Current Anesthesiology Reports 2014; 4(2): 170-6.

45. Della Rocca G, Coccia C, Pompei L, Costa MG, Di Marco P, Pietropaoli P. Inhaled aerosolized prostaglandin E1, pulmonary hemodynamics, and oxygenation during lung transplantation. Minerva Anestesiol. 2008;74(11):627-33.).

46. Walsh AM, Lohser J. Arterial oxygenation and management of hypoxemia during VATS. Current Anesthesiology Reports 2014; 4(2): 170-6.

47. Paven D, Muret J, Beloucif S, Gatecel C, Kermarrec N, Guinard N, Mateo J. Inhaled nitric oxide, almitrine infusion, or their coadministration as a treatment of severe hypoxemic focal lung lesions. Anesthesiology. 1998;89(5):1157-65.).

48. Elhakim M, Abdelhamid D, Abdelfattach H, et al. Effect of epidural dexmedetomidine on intraoperative awareness and postoperative pain after one lung ventilation. Acta Anaesthesiol Scand 2010; 54: 703-9.

49. Figueroa XF, Poblete MI, Boric MP, et al. Clonidine-induced nitric oxide dependent vasorelaxation mediated by endothelial a2-adrenoceptor activation. Br J Pharmacol 2001; 134: 957-68.

50. Walmrath D, Schneider T, Schermuly R, et al. Direct comparison of inhaled nitric oxide and aerosolized prostacyclin in acute respiratory distress syndrome. Am J Respir Crit Care Med 1996; 991-6.

51. Raghunathan K, Connelly NR, Robbins LD, et al. Inhaled epoprostenol during one-lung ventilation. Ann Thorac Surg 2010; 89: 981-3.

52. Hambraeus-Jonzon K, Bindslev L, Mellgard AJ, Hedenstierna G. Hypoxic pulmonary vasoconstriction in human lungs. A stimulus response study. Anesthesiology 1997; 86: 308-15. 
53. Tarry D, Powell M. Hypoxic pulmonary vasoconstriction. BJA Education 2017; 17(6): 208-213.

54. Howard P, Barer GB, Thompson B, Warren PM, Abbott CJ, Mungallab PF. Factors causing and reversing vasoconstriction in unventilated lung. Respiration Physiology 1975; 24(3): 325-45)

55. Ishibe Y, Gui X, Uno H, et al. Effect of sevoflurane on hypoxic pulmonary vasoconstriction in the perfused rabbit lung. Anesthesiology 1993; 79: 1348-53.

56. Loer SA, Scheeren TW, Tarnow J. Desflurane inhibits hypoxic pulmonary vasoconstriction in isolated rabbit lungs. Anesthesiology 1995; 83: 552-6.

57. Reid CW, Slinger PD, Lenis S. A comparison of the effects of propofol-alfentanil versus isoflurane anesthesia on arterial oxygenation during one-lung ventilation. J Cardiothorac Vasc Anesth 1996; 860-3.

58. Abe K, Shimizu T, Takashina M, et al. The effects of propofol, isoflurane, and sevoflurane on oxygenation and shunt fraction during one-lung ventilation. Anesth Analg 1998: 87: 1164-9.

59. Beck DH, Doepfmer UR, Sinemus C, et al: Effects of sevoflurane and propofol on pulmonary shunt fraction during one-lung ventilation for thoracic surgery. $\mathrm{Br} \mathrm{J}$ Anaesth 2001; 86: 38-43.

60. Pruszkowski O, Dalibon N, Moutafis M, et al: Effects of propofol vs. sevoflurane on arterial oxygenation during one-lung ventilation. Br J Anaesth 2007; 98: 539-44.

61. Fukuoka N, Iida H, Akamatsu S, et al. The association between the initial end tidal carbon dioxide difference and the lowest arterial oxygen tension value obtained during one-lung anesthesia with propofol or sevoflurane. J Cardiothorac Vasc Anesth 2009; 23: 775-9.

62. Howard P, Barer GB, Thompson B, Warren PM, Abbott CJ, Mungallab PF. Factors causing and reversing vasoconstriction in unventilated lung. Respiration Physiology 1975; 24(3): 325-45.

63. Prausea G, Hetzd H, Lauda P, Pojera H, Smolle-Juettnerb F, Smollec J. A comparison of the end-tidal-CO2 documented by capnometry and the arterial pCO2 in emergency patients. Resuscitation 1997; 35(2): 145-8.

64. Cinnella G, Dambrosio M, Brienza N, Giuliani R, Bruno F, Fiore T, Brienza A. Independent lung ventilation in patients with unilateral pulmonary contusion. Monitoring with compliance and EtCO2. Intensive Care Medicine 2001; 27(12): 1860-7.

65. Karzai W, Schwarzkopf K. Hypoxemia during One-lung Ventilation: Prediction, Prevention, and Treatment. Anesthesiology 2009; 110: 1402-1411.

66. Yamamoto Y, Watanabe S, Kano T. Gradient of bronchial end-tidal CO2 during two-lung ventilation in lateral decubitus position is predictive of oxygenation disorder during subsequent one-lung ventilation. J Anesth 2009; 23: 192-7.

67. Hemmerling TM, Bluteau MC, Kazan R, Bracco D. Significant decrease of cerebral oxygen saturation during single-lung ventilation measured using absolute oxymetry. Br J Anaesth 2008; 101: 870-5. 